\title{
Controlling COVID-19 Pandemic through Wastewater Monitoring
}

\author{
Djamel Ghernaout ${ }^{1,2 *}$, Badia Ghernaout ${ }^{3}$ \\ ${ }^{1}$ Chemical Engineering Department, College of Engineering, University of Ha'il, Ha'il, Saudi Arabia \\ ${ }^{2}$ Chemical Engineering Department, Faculty of Engineering, University of Blida, Blida, Algeria \\ ${ }^{3}$ Laboratory of Mechanics (LME), Department of Mechanical Engineering, University of Laghouat, Laghouat, Algeria \\ Email: ^djamel_andalus@hotmail.com
}

How to cite this paper: Ghernaout, D. and Ghernaout, B. (2020) Controlling COVID-19 Pandemic through Wastewater Monitoring. Open Access Library Journal, 7: e6411. https://doi.org/10.4236/oalib.1106411

Received: May 10, 2020

Accepted: May 23, 2020

Published: May 26, 2020

Copyright $\odot 2020$ by author(s) and Open Access Library Inc.

This work is licensed under the Creative Commons Attribution International License (CC BY 4.0).

http://creativecommons.org/licenses/by/4.0/

\begin{abstract}
The continuing global pandemic of coronavirus disease 2019 (COVID-19) produced via severe acute respiratory syndrome coronavirus 2 (SARS-CoV-2) has been a Public Health Emergency of International Concern. Even if the main transmission pathways of SARS-CoV-2 are inhalation from person-to-person and aerosol/droplet transmission, it is proved that the viral ribonucleic acid (RNA) could occur in wastewater, proposing the necessity to better comprehend wastewater as possible sources of epidemiological data and human health risks. This review focuses on the fate and transport of enteric pathogens in nature. A special interest is accorded to viruses and COVID-19. Further, this work discusses the present facts concerning the proof for the emergence of SARS-CoV-2 and related CoVs in wastewater, controlling wastewater for comprehending COVID-19, and endurance and demobilization of CoVs and enveloped surrogate viruses in water and wastewater matrices. There has been growing evidence of gastrointestinal symptoms provoked by SARS-CoV-2 contagions and the occurrence of viral RNA not only in feces of COVID-19 patients but in wastewater. One of the main dares in SARS-CoV-2 detection/quantification in wastewater samples is the shortage of an optimized and standardized protocol. The present comprehension of the possible contribution of wastewater in SARS-CoV-2 transmission is considerably restricted by knowledge gaps in its presence, endurance, and elimination in wastewater. There is a pressing necessity for additional study to define strategies for wastewater observation and comprehend the consequences of the appearance of SARS-CoV-2 in wastewater.
\end{abstract}

\section{Subject Areas}

Environmental Chemistry, Public Health 


\section{Keywords}

Coronavirus Disease 2019 (COVID-19), Severe Acute Respiratory Syndrome

Coronavirus 2 (SARS-CoV-2), Wastewater-Based Epidemiology (WBE),

Wastewater Treatment, Pathogens, Viruses

\section{Introduction}

Even if persons are constantly revealed to a large range of microorganisms in nature, only a small part of such microbes are able of interacting with the host in such a fashion that infection and illness will end in [1] [2] [3]. Disease-causing microorganisms are named pathogens [4] [5] [6]. Infection is the phenomenon by which the microorganism multiplies or grows in or on the host [1] [7] [8]. Infection does not inevitably conduct to illness as it is conceivable for the organism to grow in or on the host without provoking disease [9] [10] [11]. As an example, in the situation of enteric infections (i.e., diarrhea) induced by Salmonella, only half of the persons infected grow symptoms of the disease. An obvious pathogen is a microorganism apt for generating illness in both normal healthy and immunocompromised individuals. Opportunistic pathogens are frequently apt for provoking infections only in immunocompromised persons like burn patients, patients taking antibiotics, those with impaired immune systems, or elderly patients with diabetes. Opportunistic pathogens are current in nature and can occur in the human gut or skin without provoking illness [1].

To occasion disease, the pathogen has frequently first to expand inside or on the host. The period from infection to the manifestation of symptoms (diarrhea, fever, rash, etc.) is the incubation time (Table 1). Such time could extend from 6 to 12 hours in the case of norovirus diarrhea, or up to 30 to 60 days for the hepatitis A virus, which provokes liver disease. At any moment throughout infection, the pathogen may be liberated into nature by the host in feces, urine, or respiratory secretions. Even if the maximum liberation can happen at the highest point of the illness, it may also come before the initial symptoms. In the case of the hepatitis A virus, the maximum excretion in the feces takes place before the onset of signs of clinical disease. The level of organisms liberated into nature changes with the kind of organism and the pathway of transmission (Table 2). The level of enteric viruses throughout gastroenteritis can be as elevated as $10^{10}-10^{12}$ per gram of feces [1].

Pathogenic microorganisms commonly arise from an infected host (either human or either animal), or directly from nature. Numerous human pathogens could only be transmitted via direct or near contact with an infected person or animal. Examples comprise the herpes virus, Neisseria gonorrhoeae (gonorrhea), and Treponema pallidum (syphilis). This is due to their survival period outside the host is quite short. Pathogens transmitted through nature can survive from hours to years outside the host, depending on the organism and nature. 
Table 1. Incubation period for usual enteric pathogens [1].

\begin{tabular}{|c|c|c|c|}
\hline Agent & Incubation time & Fashions of transmission & $\begin{array}{l}\text { Duration } \\
\text { of disease }\end{array}$ \\
\hline Adenovirus & 8 - 10 days & Fecal-oral-respiratory & 8 days \\
\hline Campylobader jejuni & 3 - 5 days & Food ingestion, direct contact & 2 - 10 days \\
\hline Cryptosporidium & 2 - 14 days & $\begin{array}{l}\text { Food or water ingestion, } \\
\text { direct and indirect contact }\end{array}$ & Weeks to months \\
\hline $\begin{array}{c}\text { Escherichia coli } \\
\text { (enterotoxigenic-ETEC) }\end{array}$ & $16-72 \mathrm{~h}$ & Food or water ingestion & 3 - 5 days \\
\hline $\begin{array}{c}\text { E.coli } \\
\text { (enteropathogenic-EPEC) }\end{array}$ & $16-48 \mathrm{~h}$ & $\begin{array}{l}\text { Food or water ingestion, } \\
\text { direct and indirect contact }\end{array}$ & 5 - 12 days \\
\hline $\begin{array}{c}\text { E. coli } \\
\text { (enterohemorrhagic-EHEC) }\end{array}$ & $72-120 h$ & $\begin{array}{c}\text { Food/ingestion, } \\
\text { direct or indirect contact }\end{array}$ & 2 - 15 days \\
\hline Giardia lamblia & 7 - 14 days & $\begin{array}{l}\text { Food or water ingestion, direct } \\
\text { and indirect contact }\end{array}$ & Weeks to months \\
\hline Norovirus & $24-48 \mathrm{~h}$ & $\begin{array}{l}\text { Food or water ingestion, direct } \\
\text { and indirect contact, aerosol? }\end{array}$ & 1 - 2 days \\
\hline Rotavirus & $24-72 \mathrm{~h}$ & Direct and indirect contact & 4 - 6 days \\
\hline Hepatitis A & $30-60$ days & Fecal-oral, fomites & 2 - 4 weeks \\
\hline Salmonella & $16-72 \mathrm{~h}$ & $\begin{array}{l}\text { Food ingestion, } \\
\text { direct and indirect contact }\end{array}$ & 2 - 7 days \\
\hline Shigella & $16-72 \mathrm{~h}$ & $\begin{array}{l}\text { Food or water ingestion, direct } \\
\text { and indirect contact }\end{array}$ & 2 - 7 days \\
\hline Yersinia enterocolitica & 3 - 7 days & Food ingestion, direct contact & 1 - 3 weeks \\
\hline
\end{tabular}

Table 2. Concentration of enteric pathogens in feces [1].

\begin{tabular}{cc}
\hline Organism & Per gram of feces \\
\hline Protozoan parasites & $10^{6}-10^{7}$ \\
Helminths & $10^{4}-10^{5}$ \\
Ascaris & \\
Enteric viruses & $10^{3}-10^{7}$ \\
Enteroviruses & $10^{10}$ \\
Rotavirus & $10^{11}$ \\
Adenovirus/Norovirus & \\
Enteric bacteria & $10^{4}-10^{10}$ \\
Salmonella spp. & $10^{5}-10^{9}$ \\
Shigella & \\
Indicator bacteria & $10^{7}-10^{9}$ \\
Coliforms & $10^{6}-10^{9}$ \\
Fecal coliforms & \\
\hline
\end{tabular}


Pathogens could exit a host in respiratory secretions from the nose and mouth, or be shed on dead skin or in feces, urine, saliva, or tears. Therefore, they may pollute the air, water, food, or inanimate objects (fomites). When polluted air is inhaled or food consumed, the organisms are efficiently transmitted to another host, where the infection phenomenon starts again. Airborne transmission could happen through liberation from the host in droplets (i.e., coughing) or via natural (surf at a beach) or human activities (cooling towers, showers). Several organisms could be carried important distances, hundreds of meters (like Legionnaires' disease and foot-and-mouth disease). Virus transmission via the airborne pathway can be both direct and indirect. The contagion of a host could be by direct inhalation of infectious droplets or via contact with fomites on which the airborne droplets have settled. Hand or mouth contact with the organism on the surface of fomite leads to the transfer of the organism to the portal of entry, i.e., nose, mouth, or eye [1].

Microorganisms transmitted by the fecal-oral pathway are commonly mentioned as enteric pathogens since they spread the disease to the gastrointestinal tract. They are peculiarly stable in water and food, and, in the instance of enteric bacteria, are apt for development outside the host under the suitable ecological conditions [1].

Waterborne diseases (Table 3) are those transmitted via the ingestion of polluted water that works as the passive carrier of the infectious agent. The traditional waterborne diseases, cholera and typhoid fever, which have considerably damaged densely populated regions during human history, have been efficiently dominated via the protection of water sources and via the treatment of polluted water supplies. Indeed, dominating such traditional diseases lights the significance of water supply treatment which greatly contributed to the decrease of infectious illnesses. Additional illnesses provoked by bacteria, viruses, protozoa, and helminths may as well be transmitted via polluted potable water. Nevertheless, it is crucial to keep in mind that waterborne diseases are transmitted by the fecal-oral route, from human to human or animal to human, so that potable water is only one of numerous probable sources of infection [1].

Table 3. Classification of water-related illnesses associated with microorganisms [1].

\begin{tabular}{|c|c|c|}
\hline Class & Cause & Example \\
\hline Waterborne & $\begin{array}{l}\text { Pathogens that originate in fecal material and are } \\
\text { transmitted by ingestion }\end{array}$ & $\begin{array}{l}\text { Cholera, } \\
\text { typhoid fever }\end{array}$ \\
\hline Water-washed & $\begin{array}{l}\text { Organisms that originate in feces are transmitted through } \\
\text { contact because of inadequate sanitation or } \\
\text { hygiene }\end{array}$ & Trachoma \\
\hline Water-based & $\begin{array}{l}\text { Organisms that originate in the water or spend part of } \\
\text { their life cycle in aquatic animals and come in direct } \\
\text { contact with humans in water or by inhalation }\end{array}$ & $\begin{array}{l}\text { Schistosomiasis, } \\
\text { Legionellosis }\end{array}$ \\
\hline Water-related & $\begin{array}{l}\text { Microorganisms with life cycles associated with insects } \\
\text { that live or breed in water }\end{array}$ & Yellow fever \\
\hline
\end{tabular}


Water-washed illnesses are intimately related to bad hygiene and wrong sanitation. In such a situation, the accessibility of enough amount of water is usually viewed as more significant than the standard of the water. The shortage of water for washing and bathing participates in illnesses that have an effect on the eye and skin, comprising infectious conjunctivitis and trachoma, as well as in diarrhea diseases, which are a prime source of infant mortality and morbidity in poor countries. Diarrheal illnesses could be immediately transmitted via person-to-person contact, or indirectly via contact with infected foods and utensils employed by persons whose hands are fecally polluted. When sufficient water is accessible for hand washing, the happening of diarrheal illnesses has been illustrated to lower considerably, as has the prevalence of enteric pathogens like Shigella [1].

Water-based illnesses are provoked by pathogens that either spend all (or crucial parts) of their lives in water or depend on aquatic organisms for the completion of their life cycles. Instances of these organisms are the parasitic helminth Schistosoma and the bacterium Legionella, which lead to schistosomiasis and Legionnaires' disease, respectively [1].

Water-related illnesses, like yellow fever, dengue, filariasis, malaria, onchocerciasis, and sleeping sickness, are transmitted via insects that multiply in water (like mosquitoes that transfer malaria) or live near water (e.g., the flies that transmit the filarial infection onchocerciasis). Such insects are known as vectors [1].

This review focuses on the fate and transport of enteric pathogens in nature. A special interest is accorded to viruses and COVID-19. Further, this work discusses the present facts concerning the proof for the emergence of SARS-CoV-2 and related CoVs in wastewater, controlling wastewater for comprehending COVID-19, and endurance and demobilization of CoVs and enveloped surrogate viruses in water and wastewater matrices.

\section{Viruses Background}

\subsection{Enteric Viruses}

Throughout the globe, viruses are a most important reason for gastroenteritis, especially in infants and young children, in which they are the main reason for mortality. Four main groups of human gastroenteritis viruses have been classified: rotavirus (Figure 1); enteric adenovirus (Figure 2); caliciviruses (norovirus and Sapporo virus); and astrovirus (Table 4). From these, norovirus is of concern since it has become the enteric virus most frequently related to water- and foodborne disease throughout the globe. Even if endemic viral gastroenteritis could be transmitted person to person by the oral-fecal pathway, eruptions of viral gastroenteritis can be initiated through infection of common water or food source [1].

Several human viruses could contaminate the gastrointestinal tract and be excreted in the feces into nature. A person with an enteric viral infection can excrete $10^{11}$ viral particles per gram of feces (Table 2). Once in nature, viruses could attain water supplies, recreational waters, crops, and shellfish, via contact with sewage, land runoff, solid waste landfills, and septic tanks [1]. 


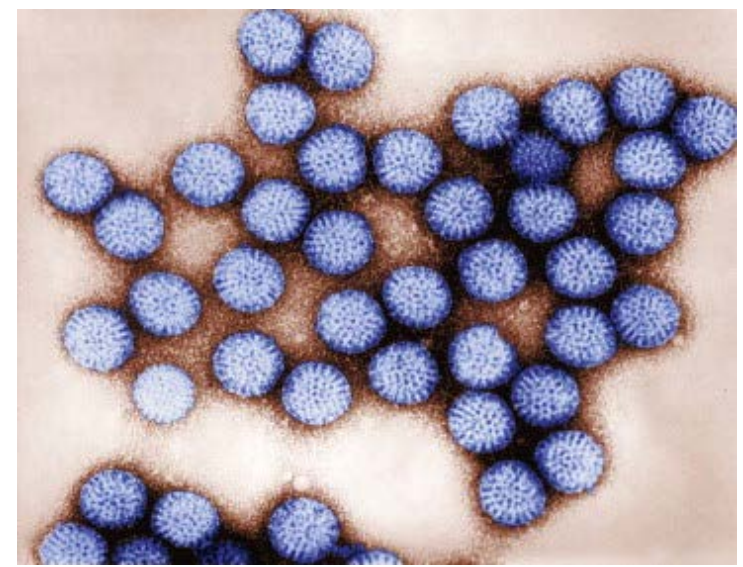

Figure 1. Electron micrograph of human rotavirus [1].

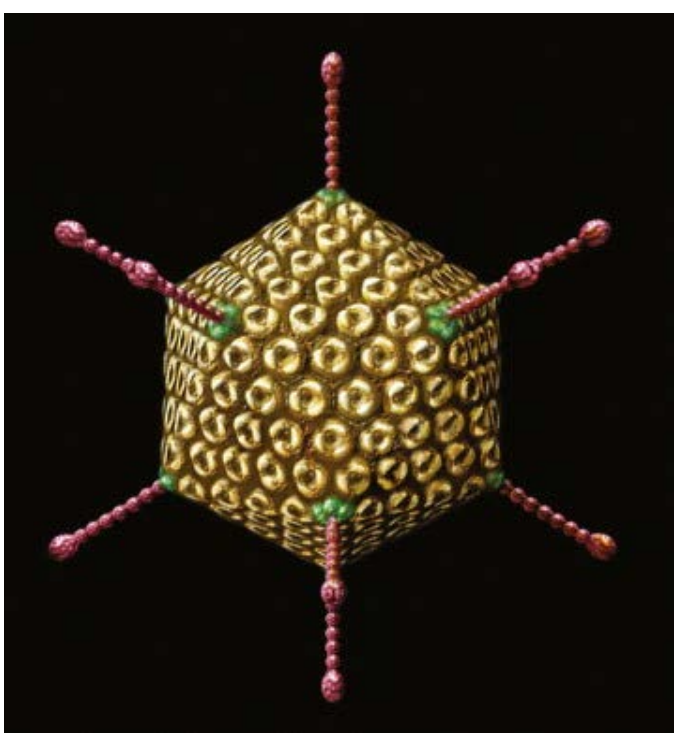

Figure 2. Adenovirus [1].

Table 4. Human enteric viruses [1].

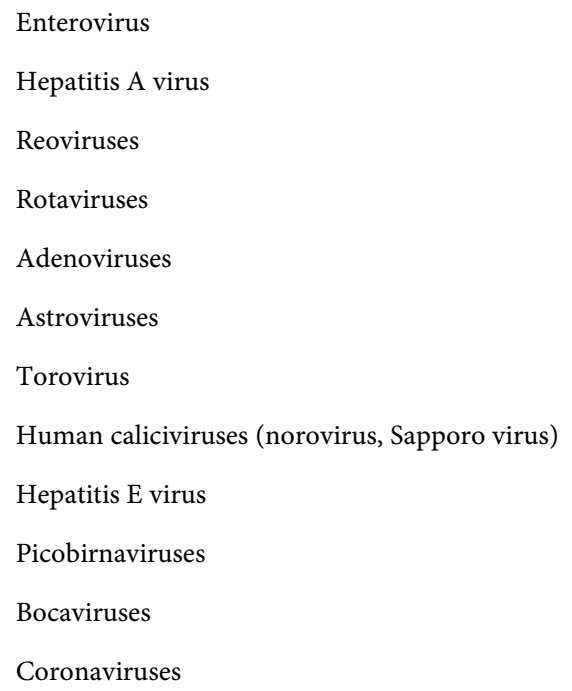


Illnesses provoked via enteric viruses spread from slight to dangerous or even deadly. Waterborne eruptions formed by enteric viruses are complicated to report since numerous infections by such pathogens are subclinical. It means that the virus may replicate in a person, leading to virus shedding even if without symptoms of the apparent disease. On that account, a person with waterborne contamination but without apparent illness can contaminate others, who in turn can become ill, diffusing the infection throughout the society. Moreover, epidemiological techniques lack the responsiveness to discover low-level transmission of viruses via the water. Recreational activities in swimming pools have sometimes resulted in waterborne outbreaks caused by norovirus, hepatitis A virus, coxsackievirus (Figure 3), echovirus, and adenoviruses. Enteric viruses from contaminated persons could pollute recreational waters via direct contact or by fecal release [1].

\subsection{Respiratory Viruses}

Throughout the globe, respiratory diseases are the most frequent diseases in humans and most possess a viral etiology. Respiratory illness is related to a big number of viruses, comprising rhinoviruses (Figure 4); coronaviruses; parainfluenza viruses; respiratory syncytial virus (RSV); influenza virus; and adenovirus. Such viruses, when they contaminate the upper respiratory tract, could provoke acute viral rhinitis or pharyngitis (common cold); when the primary site of infection is the lower respiratory tract, they could lead to laryngotracheitis (croup), bronchitis or pneumonia [1].

Mortality linked to acute respiratory illness could be particularly considerable in children and in the elderly. In adults, temporary disability leads to huge economic loss. Respiratory infection frequently results from self-inoculation, when

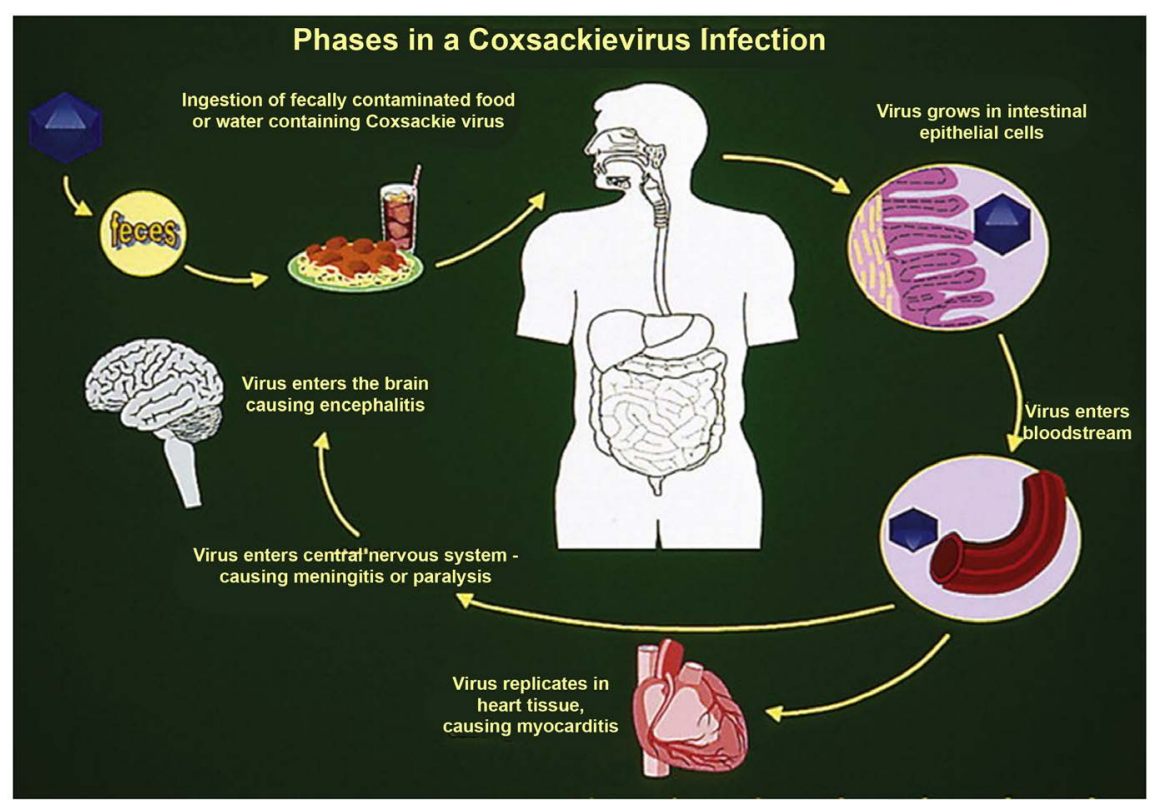

Figure 3. Infection by coxsackieviruses [1]. 


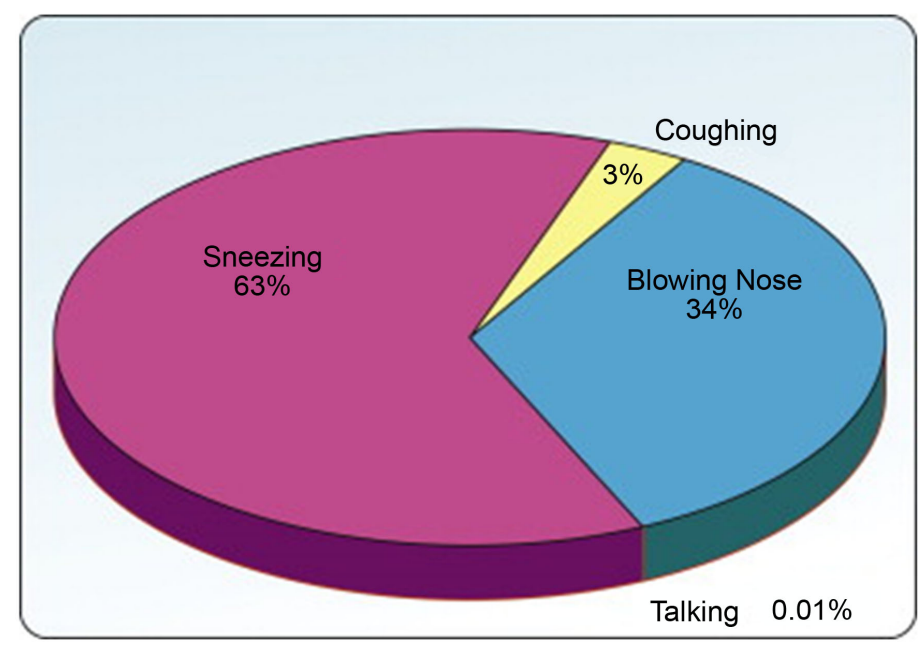

Figure 4. Source of rhinovirus dispersion [1].

virus-contaminated hands or fingers rub the eyes or when viruses are introduced into the mouth or nose. Another significant pathway of transmission of respiratory viruses is the inhalation of contaminated aerosols [1].

\section{Fate and Transport of Enteric Pathogens in Nature}

There are numerous possible pathways for the transmission of excreted enteric pathogens [12] [13] [14]. The possibility of an enteric pathogen to be transmitted by any of such pathways relies considerably on its resistance to ecological features [15] [16] [17], which dominate its survival and its capability to be transferred by water or air, as it moves through the environment [18] [19] [20]. Numerous pathways could be categorized as "natural" pathways for the transmission of waterborne illness [21] [22] [23]; however, others (like the usage of urban wastewater for groundwater recharge, large-scale aquaculture projects, or land disposal of disposable diapers) are in fact novel pathways generated by modern human activities [1] [24] [25].

Human and animal excreta are sources of pathogens. Persons become contaminated via pathogens during consumption of polluted foods, like shellfish from infected waters or crops irrigated with wastewater; from potable polluted water; and via vulnerability to polluted surface waters, as may happen throughout bathing or at recreational sites. Moreover, such humans contaminated by the above routes become sources of pollution via their excrement, thereby completing the cycle [1].

In the main, viral and protozoan pathogens survive longer in nature than enteric bacterial pathogens (Table 5). How long a pathogen survives in a specific medium is a function of many complicated characteristics (Table 6). Of all of the elements, the temperature remains likely the most significant. Temperature is a well-defined element with a systematically anticipated impact on enteric pathogen survival in nature. As a rule, the lower the temperature, the longer the survival time. Nevertheless, freezing temperatures usually conduct to the death of 
Table 5. Survival times of enteric pathogens in water, wastewater, and soil and on crops [1].

\begin{tabular}{ccc}
\hline Enteric pathogen & Excreted load $^{\mathrm{a}}$ & Survival (months) $^{\mathrm{b}}$ \\
\hline Campylobacter $\mathrm{spp}$. & $10^{7}$ & $1 / 3$ \\
Giardia lamblia & $10^{5}$ & $2 / 3$ \\
Shigella spp. & $10^{7}$ & 1 \\
Vibrio cholerae & $10^{7}$ & 1 \\
Salmonella spp. & $10^{8}$ & 3 \\
E. coli (pathogens) & $10^{8}$ & 3 \\
Enteroviruses & $10^{7}$ & 3 \\
Hepatitis A virus & $10^{6}$ & 3 \\
Ancylostoma duodenale & $10^{2}$ & 3 \\
Taenia saginata & $10^{4}$ & 12 \\
Ascaris lumbricoides & $10^{4}$ & 9 \\
\hline
\end{tabular}

${ }^{a}$ Typical average number of organisms $/ \mathrm{g}$ feces. ${ }^{b}$ Estimated average life of infective stage at $20^{\circ} \mathrm{C}-30^{\circ} \mathrm{C}$.

Table 6. Ecological elements influencing enteric pathogen survival in natural waters [1].

\begin{tabular}{cl}
\hline Element & \multicolumn{1}{c}{ Remarks } \\
Temperature & $\begin{array}{l}\text { Probably the most important factor; longer survival at lower } \\
\text { temperatures; freezing kills bacteria and protozoan parasites, but } \\
\text { prolongs virus survival. }\end{array}$ \\
Moisture & Low moisture content in soil can reduce bacterial populations. \\
Light & UV in sunlight is harmful. \\
pH & $\begin{array}{l}\text { Most are stable at pH values of natural waters. Enteric bacteria are } \\
\text { less stable at pH }>9 \text { and pH }<6 . \\
\text { Salts }\end{array}$ \\
Some viruses are protected against heat inactivation by the \\
presence of certain cations. \\
Suspended solids or
\end{tabular}

enteric bacteria and protozoan parasites. Even so, enteric viruses could stay infectious for months or years at freezing temperatures. Moisture-or lack thereof-could provoke reduced survival, and UV light from the sun is the main element in the demobilization of indicator bacteria in surface waters; therefore, die-off in marine waters could be anticipated by amount of exposure to daylight. Viruses stay much more resistant to demobilization by UV light [1].

Several laboratory investigations have established that the microflorae of natural waters and sewage are hostile to the survival of enteric pathogens [26] [27] [28]. As an illustration, enteric pathogens survive longer in sterile water than in water from lakes, rivers and oceans [29] [30] [31]. Bacteria in natural waters can 
feed upon indicator bacteria [32]. Suspended matter (clays, organic debris, and the like) and fresh or marine sediments have been shown to prolong their survival time (Figure 5) [1] [33] [34].

\section{COVID-19}

At the end of 2019, China announced an eruption of pneumonia of unknown etiology occurring in Wuhan (Hubei Province) [35]. Preliminary investigations affirmed that this eruption was related to a new coronavirus (nCoV) [36]. The nCoV was proved to possess $75 \%-80 \%$ nucleotide similarity to severe acute respiratory syndrome coronavirus (SARS-CoV) [36] and was formally named as SARS-CoV-2 after being provisionally called as 2019-nCoV [35]. SARS-CoV-2 and SARS-CoV belong to the species Severe Acute Respiratory Syndrome-related Coronavirus in the subgenus Sarbecovirus of the family Coronaviridae that comprises a group of enveloped viruses with a single-stranded, positive-sense ribonucleic acid (RNA) genome. SARS-CoV and SARS-CoV-2 are distantly related to the Middle East respiratory syndrome coronavirus (MERS-CoV), which belongs to the Middle East Respiratory Syndrome-related Coronavirus species within the genus Betacoronavirus [35]. Further, SARS-CoV-2 is distantly linked to "classical" human CoV strains (229E, OC43, NL63, and HKU1) belonging to the genus Alphacoronavirus or Betacoronavirus that have been investigated since the 1960s and are evaluated to rise $15 \%-30 \%$ of cases of frequent colds through the globe [35].

The illness provoked by SARS-CoV-2 is alluded to as coronavirus disease 2019 (COVID-19). Signs of COVID-19 at the beginning of disease comprise fever, myalgia, fatigue, and dry cough, and more than half of the patients developed dyspnea [35]. On March 11, 2020, it was announced that the present COVID-19 situation a global pandemic on the basis of "alarming levels of spread and severity, and by the alarming levels of inaction" [35].

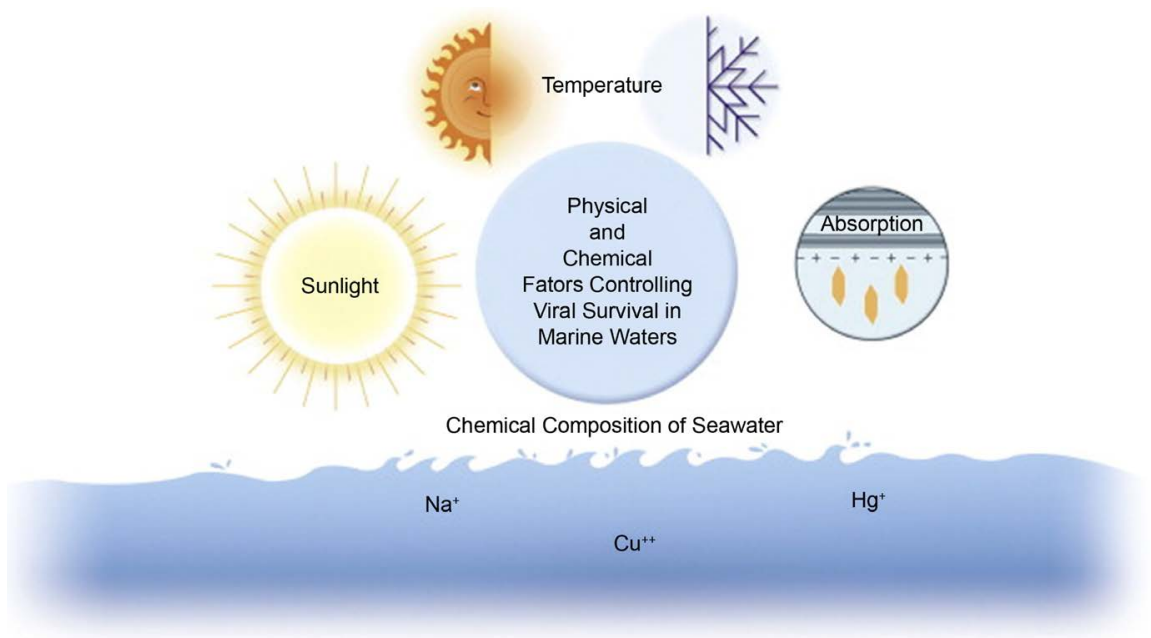

Figure 5. Elements influencing the survival of enteric bacteria and viral pathogens in seawater [1]. 
Both viable SARS-CoV-2 and viral RNA are shed in bodily excreta, comprising saliva, sputum, and feces, which are posteriorly observed in wastewater. Even if it is accepted that the main transmission pathway of such viruses is inhalation via person-to-person and aerosol/droplet transmission and fomite and hand contamination, presently obtainable evidence shows the necessity for better comprehension of the function of wastewater [37] [38] [39] as a possible source of epidemiological data and as an element in the public health hazard. Recently, Kitajima et al. [35] rigorously consulted the actual information linked to the possibility of wastewater monitoring [40] [41] [42] for grasping the epidemiology of COVID-19. Considering the fast germination of SARS-CoV-2, acquired knowledge on human CoVs, SARS-CoV, MERS-CoV, and surrogate viruses could assist to tell prognosis of the probable ecological destiny and following dangers of SARS-CoV-2. Further, they defined important research necessities that will enhance comprehension of the appearance, continuity, and probable public health dangers related to SARS-CoV-2 in wastewater.

In the next sections, a special focus will be accorded to the proof for the emergence of SARS-CoV-2 and related CoVs in wastewater, controlling wastewater for comprehending COVID-19, and endurance and demobilization of CoVs and enveloped surrogate viruses in water and wastewater matrices.

\subsection{Proof for the Appearance of SARS-CoV-2 and Related CoVs in Wastewater}

Since CoVs are enveloped viruses that are hypothesized to be mostly diffused via person-to-person contact rather than the fecal-oral route (which has been assumed but not proved), their occurrence in feces needs more precise explanation and the existence of viral RNA in wastewater [43] [44] [45] has not earned general employment as an illness monitoring implement; however, it is acquiring an interest in such direction [46]. Moreover, it was established that standard virus concentration procedures are incapable to recover enveloped viruses from ecological water samples [47] [48]. Regardless of such thoughts, one of the earliest discoveries of CoVs in wastewater was performed in 2013 [49]. Such investigation worked on the discovery of deoxyribonucleic acid (DNA) and RNA viruses during a 12-month survey in the USA and CoVs were detected in wastewater in 1 of 12 samples employing microarrays. Wong et al. [49] concentrated on non-enveloped enteric viruses and this revelation was not followed up with RT-qPCR to gain quantitative data. At the same time, a viral metagenomic investigation allowing for untargeted molecular analysis of the whole viral community identified the CoV HKU1 genome (a "common cold" CoV) in sewage sludge [50], furnishing rebuttal for $\mathrm{CoV}$ occurrence in wastewater. Last year, an investigation mentioned the molecular detection of animal $\mathrm{CoV}$ belonging to the genus Alphacoronavirus in surface water in Saudi Arabia [51]. Throughout the SARS eruption in 2004 in China, SARS-CoV RNA was revealed in 100\% (10/10) of untreated and $30 \%(3 / 10)$ of disinfected wastewater samples gathered from a 
hospital in Beijing (China) receiving SARS patients [35]. Wastewater was also suspected to be at least rather in charge of a typical SARS eruption because of an incorrect ventilation and plumbing system [52]. There have been first accounts of the molecular detection of SARS-CoV-2 in wastewater in numerous countries [35]. The revelation of SARS-CoV-2 RNA in untreated wastewater with levels of a maximum of over $10^{6}$ copies/L was noted. Further, an investigation discovered SARS-CoV-2 RNA in treated wastewater as well, with levels of up to nearly $10^{5}$ copies/L [35].

\subsection{Monitoring Wastewater for Comprehending COVID-19}

Wastewater-based epidemiology (WBE) could be utilized as a valuable implement to follow the circulation of viruses in a community, furnishing possibilities to evaluate their spread, genetic diversity, and geographic distribution [53]. Wastewater systems provide a functional manner to recognize viruses excreted in the feces of an entire area [35] [54] [55]. Employing such a procedure, it will be easy to watch the epidemiology of virus contagions even if they are not obvious via clinical control, mostly due to conventional epidemiological procedures can be restricted by the asymptomatic kind of numerous viral diseases and underdiagnosis of clinical cases [56] [57] [58]. Such restrictions are usable for not only fecally-shed viruses like adenovirus, norovirus, sapovirus, enterovirus, rotavirus, and hepatitis A virus [59], but also for different viruses that are scarcely or never noted by epidemiological surveillance systems (e.g., Saffold virus, cosavirus, and salivirus/klassevirus) [60].

SARS-CoV-2 is recognized to provoke asymptomatic or pauci-symptomatic contagions [61] rendering it hard to evaluate the real level of viral circulation in a community and in making juxtapositions between diverse nations that possess varying clinical diagnostic testing capabilities with even diverse diagnostic methods/assays [35]. For now, wastewater observation can furnish an impartial procedure of estimating the diffusion of contamination in diverse regions, paradoxically where resources for clinical diagnosis are restricted and when reporting systems are unavailable or not practicable, like in poor nations. Further, wastewater controlling could assist to discover changes in the circulating strains via phylogenetic analysis, letting for juxtapositions among areas and estimation of the expansion of the virus genome over time as proved already for enteric viruses, and more recently for SARS-CoV-2 [35].

\subsection{Endurance and Demobilization of CoVs and Enveloped Surrogate Viruses in Water and Wastewater Matrices}

The extent of human health hazards changes following the decomposition of pathogens, comprising SARS-CoV-2 in water mediums. Comprehending the decomposition of SARS-CoV-2 and its RNA will, in the end, enhance monitoring procedures and wastewater treatment demands; however, little has been published on the endurance of CoVs in water and wastewater matrices. Wang et al. [62] studied the endurance of SARS-CoV, E. coli and $\mathrm{f} 2$ phage in hospital waste- 
water, urban sewage, tap water, phosphate-buffered saline, feces, urine, water, and wastewater with high changing levels $(5,10,20$ and $40 \mathrm{mg} / \mathrm{L})$ of chlorine [63] [64] [65] and chlorine dioxide. Further, they examined the impact of residence period on demobilization of SARS-CoV in wastewater with small $(10 \mathrm{mg} / \mathrm{L}$ chlorine [66] [67] [68] and chlorine dioxide) and elevated (20 mg/L of chlorine and $40 \mathrm{mg} / \mathrm{L}$ of chlorine dioxide) dosages. Findings illustrated that coronavirus endured longer (inoculated titer of $10^{5}$ median tissue culture infectious dose $\left(\mathrm{TCID}_{50}\right)$; detectable with reverse transcription polymerase chain reaction (RT-PCR) for 14 days) at $4^{\circ} \mathrm{C}$ juxtaposed to $20^{\circ} \mathrm{C}$ (3 days) in hospital wastewater, domestic sewage, and dechlorinated tap water. At $20^{\circ} \mathrm{C}$, SARS-CoV continued in three fecal samples for 3 days and two urine samples for 17 days (inoculated titer of $10^{5}$ $\left.\mathrm{TCID}_{50}\right)$. SARS-CoV was more impotent to disinfectants juxtaposed to $E$. coli and f2 phage. Free chlorine was more efficacious in killing SARS-CoV than chlorine dioxide. Free residue chlorine of $>0.5 \mathrm{mg} / \mathrm{L}$ or chlorine dioxide of $2.19 \mathrm{mg} / \mathrm{L}$ in wastewater were enough for the total elimination of SARS-CoV [35].

Gundy et al. [69] followed the survival of human CoV 229E and enteric feline $\mathrm{CoV}$ (ATCC-990) in water and wastewater employing plaque assay or $\mathrm{TCID}_{50}$ technique. The times for $99 \%$ and $99.9 \%$ demobilization $\left(T_{99}\right.$ and $\mathrm{T}_{99.9}$, respectively) were evaluated for filtered and unfiltered tap water at $23^{\circ} \mathrm{C}$, filtered tap water at $4^{\circ} \mathrm{C}$, filtered and unfiltered primary effluent at $23^{\circ} \mathrm{C}$ and secondary effluent (activated sludge) at $23^{\circ} \mathrm{C}$. The survival of both human and feline CoVs depicted identical patterns and was substantially dependent on water temperature, the concentration of organic matter, and biological activity. The $T_{99}$ for tap water for both human and feline $\mathrm{CoV}$ were quicker at $23^{\circ} \mathrm{C}(7-9$ days $)$ than $4^{\circ} \mathrm{C}$ (>87 days). The demobilization rates of both $\mathrm{CoVs}$ were quicker in filtered tap water juxtaposed to unfiltered tap water at $23^{\circ} \mathrm{C}$, suggesting augmented protection and survival in the occurrence of organic matter and suspended solids. CoVs were demobilized quickly in wastewater, with $T_{99}$ values of $<3$ days [35].

Casanova et al. [70] assessed the endurance of two surrogate CoVs, transmissible gastroenteritis virus (TGEV), and mouse hepatitis virus (MHV) in reagent grade water, lake water, and pasteurized settled sewage in North Carolina, USA employing quantal assays for cytopathic effect (CPE). In the main, both the surrogate viruses endured for importantly shorter periods at $25^{\circ} \mathrm{C}$ juxtaposed to $4^{\circ} \mathrm{C}$ for all water kinds. For reagent grade water, TGEV and $\mathrm{MHV}$ endured for shorter times ( $T_{99}=22$ and 16 days, respectively) at $25^{\circ} \mathrm{C}$ than at $4^{\circ} \mathrm{C}$ ( $>220$ days for both viruses). For lake water, TGEV and MHV $T_{99}$ values were 13 and 10 days, respectively, over a 14-day experiment. Nevertheless, at $4^{\circ} \mathrm{C}$, one $\log _{10}$ decrease was noted at day 14 for TGEV, while no removal was detected for MHV up to day 14 at $4^{\circ} \mathrm{C}$. Both viruses endured shorter in pasteurized settled sewage samples and $T_{99}$ removal periods were nine days for TGEV, and seven days for MHV. At $4^{\circ} \mathrm{C}, T_{99}$ values of TGEV and MHV were 49 and 70 days, respectively, proposing surrogate CoVs could stay infectious for long times in water and pasteurized settled sewage at a lower temperature [35]. 


\section{Conclusions}

This review focuses on the fate and transport of enteric pathogens in nature. A special interest is accorded to viruses and COVID-19. Further, this work discusses the present facts concerning the proof for the emergence of SARS-CoV-2 and related CoVs in wastewater, controlling wastewater for comprehending COVID-19, and endurance and demobilization of CoVs and enveloped surrogate viruses in water and wastewater matrices. From this work, the following conclusions can be drawn:

1) Now, huge knowledge gaps remain in the crucial contribution of wastewater in the transmission of SARS-CoV-2. Survival of SARS-CoV-2 in ecosystems, comprising wastewater and water, stays mainly obscure. The stability of SARS-CoV-2 is identical to that of SARS-CoV in aerosols and on surfaces. Employing an identical manner, the stability of SARS-CoV-2 in different water matrices has to be studied. The endurance of SARS-CoV-2 requires to be defined in wastewater and environmental water for tropical, subtropical, and temperate climatic zones since the endurance can be considerably changing in diverse temperatures. Further, the endurance of SARS-CoV-2 in wastewater and receiving waters and demobilization pathways, like predation, UV, sunlight [71] [72] [73], and disinfection [74] [75] [76] has to be studied. Information on SARS-CoV-2 reduction and/or demobilization by wastewater and water treatment technologies [77] [78] [79], like activated sludge, membrane filtration [80] [81] [82], coagulation-sedimentation [83] [84] [85], and disinfection (chlorine [86] [87] [88], chloramine, UV [89] [90], ozone [91], etc.) remains rare. If it is hard to estimate $\log _{10}$ removal values of SARS-CoV-2 itself due to the availability of the virus and/or biosafety restrictions, model enveloped viruses such as human CoVs, MHV, or Pseudomonas phage $\Phi 6$ could be employed for laboratory- or pilot-scale tests [35].

2) Wastewater control remains crucial because WBE could furnish important data on the spread of contagions in society. Constant and methodical observation of wastewater can give early warning signs and will greatly distinguish undiagnosed or successive disease at the population level, thus alerting public health officials on the ongoing or future viral disease outbreaks. Nationwide and international wastewater surveillance campaigns should be carried out to better understand the temporal and spatial dynamics of disease prevalence, molecular epidemiology and evolution of the virus, and efficacy of public health interventions [35].

\section{Acknowledgements}

This research has been funded by the Research Deanship of University of Ha'il, Saudi Arabia, through the Project RG-191190.

\section{Conflicts of Interest}

The authors declare no conflicts of interest regarding the publication of this paper. 


\section{References}

[1] Gerba, C.P. (2015) Environmentally Transmitted Pathogens. In: Pepper, I.L., Gerba, C.P. and Gentry, T.J., Eds., Environmental Microbiology, 3rd Edition, Elsevier Inc., Amsterdam, Ch. 22. https://doi.org/10.1016/B978-0-12-394626-3.00001-6

[2] Gerba, C.P. and Pepper, I.L. (2015) Drinking Water Treatment and Distribution. In: Pepper, I.L., Gerba, C.P. and Gentry, T.J., Eds., Environmental Microbiology, 3rd Edition, Elsevier Inc., Amsterdam, Ch. 28.

https://doi.org/10.1016/B978-0-12-394626-3.00001-6

[3] Ghernaout, D., Badis, A., Ghernaout, B. and Kellil, A. (2008) Application of Electrocoagulation in Escherichia coli Culture and Two Surface Waters. Desalination, 219, 118-125. https://doi.org/10.1016/j.desal.2007.05.010

[4] Ghernaout, D. and Ghernaout, B. (2010) From Chemical Disinfection to Electrodisinfection: The Obligatory Itinerary? Desalination and Water Treatment, 16, 156-175. https://doi.org/10.5004/dwt.2010.1085

[5] Belhout, D., Ghernaout, D., Djezzar-Douakh, S. and Kellil, A. (2010) Electrocoagulation of a Raw Water of Ghrib Dam (Algeria) in Batch Using Iron Electrodes. Desalination and Water Treatment, 16, 1-9. https://doi.org/10.5004/dwt.2010.1081

[6] Ghernaout, B., Ghernaout, D. and Saiba, A. (2010) Algae and Cyanotoxins Removal by Coagulation/Flocculation: A Review. Desalination and Water Treatment, 20, 133-143. https://doi.org/10.5004/dwt.2010.1202

[7] Ghernaout, D. (2019) Virus Removal by Electrocoagulation and Electrooxidation: New Findings and Future Trends. Journal of Environmental Science and Allied Research, 2019, 85-90.

[8] Ghernaout, D. and Elboughdiri, N. (2020) Environmental Engineering for Stopping Viruses Pandemics. Open Access Library Journal, 7, e6299.

[9] Ghernaout, D. and Elboughdiri, N. (2020) Disinfecting Water: Plasma Discharge for Removing Coronaviruses. Open Access Library Journal, 7, e6314. https://doi.org/10.4236/oalib.1106314

[10] Ghernaout, D. (2017) Microorganisms' Electrochemical Disinfection Phenomena. EC Microbiology, 9, 160-169.

[11] Ghernaout, D., Alghamdi, A. and Ghernaout, B. (2019) Microorganisms' Killing: Chemical Disinfection vs. Electrodisinfection. Applied Engineering, 3, 13-19.

[12] Ghernaout, D. and Elboughdiri, N. (2019) Upgrading Wastewater Treatment Plant to Obtain Drinking Water. Open Access Library Journal, 6, e5959.

https://doi.org/10.4236/oalib.1105959

[13] Ghernaout, D. and Elboughdiri, N. (2020) Electrochemical Technology for Wastewater Treatment: Dares and Trends. Open Access Library Journal, 7, e6020.

[14] Ghernaout, D., Elboughdiri, N. and Ghareba, S. (2020) Fenton Technology for Wastewater Treatment: Dares and Trends. Open Access Library Journal, 7, e6045. https://doi.org/10.4236/oalib.1106045

[15] Ghernaout, D. and Elboughdiri, N. (2020) Antibiotics Resistance in Water Mediums: Background, Facts, and Trends. Applied Engineering, 4, 1-6. https://doi.org/10.4236/oalib.1106003

[16] Ghernaout, D. and Elboughdiri, N. (2020) Removing Antibiotic-Resistant Bacteria (ARB) Carrying Genes (ARGs): Challenges and Future Trends. Open Access Library Journal, 7, e6003. https://doi.org/10.4236/oalib.1106003

[17] Ghernaout, D. and Elboughdiri, N. (2020) Should We Forbid the Consumption of 
Antibiotics to Stop the Spread of Resistances in Nature? Open Access Library Journal, 7, e6138.

[18] Ghernaout, D. and Elboughdiri, N. (2020) On the Treatment Trains for Municipal Wastewater Reuse for Irrigation. Open Access Library Journal, 7, e6088.

[19] Ghernaout, D. and Elboughdiri, N. (2020) Advanced Oxidation Processes for Wastewater Treatment: Facts and Future Trends. Open Access Library Journal, 7, e6139.

[20] Ghernaout, D. and Elboughdiri, N. (2020) Domestic Wastewater Treatment: Difficulties and Reasons, and Prospective Solutions-China as an Example. Open Access Library Journal, 7, e6141.

[21] Ghernaout, D. (2013) The Best Available Technology of Water/Wastewater Treatment and Seawater Desalination: Simulation of the Open Sky Seawater Distillation. Green and Sustainable Chemistry, 3, 68-88. https://doi.org/10.4236/gsc.2013.32012

[22] Ghernaout, D. (2018) Increasing Trends towards Drinking Water Reclamation from Treated Wastewater. World Journal of Applied Chemistry, 3, 1-9. https://doi.org/10.11648/j.wjac.20180301.11

[23] Ghernaout, D. and Elboughdiri, N. (2019) Electrocoagulation Process Intensification for Disinfecting Water-A Review. Applied Engineering, 3, 140-147.

[24] Ghernaout, D., Alshammari, Y. and Alghamdi, A. (2018) Improving Energetically Operational Procedures in Wastewater Treatment Plants. International Journal of Advances in Applied Sciences, 5, 64-72. https://doi.org/10.21833/ijaas.2018.09.010

[25] Ghernaout, D. (2019) Reviviscence of Biological Wastewater Treatment-A Review. Applied Engineering, 3, 46-55.

[26] Ghernaout, D. and Elboughdiri, N. (2020) Eliminating Cyanobacteria and Controlling Algal Organic Matter-Short Notes. Open Access Library Journal, 7, e6252. https://doi.org/10.4236/oalib.1106252

[27] Ghernaout, D., Elboughdiri, N., Ghareba, S. and Salih, A. (2020) Coagulation Process for Removing Algae and Algal Organic Matter-An Overview. Open Access Library Journal, 7, e6272. https://doi.org/10.4236/oalib.1106272

[28] Ghernaout, D. and Ghernaout, B. (2012) On the Concept of the Future Drinking Water Treatment Plant: Algae Harvesting from the Algal Biomass for Biodiesel Production-A Review. Desalination and Water Treatment, 49, 1-18. https://doi.org/10.1080/19443994.2012.708191

[29] Ghernaout, D., Benblidia, C. and Khemici, F. (2015) Microalgae Removal from Ghrib Dam (Ain Defla, Algeria) Water by Electroflotation Using Stainless Steel Electrodes. Desalination and Water Treatment, 54, 3328-3337. https://doi.org/10.1080/19443994.2014.907749

[30] Ghernaout, D., Badis, A., Braikia, G., Matâam, N., Fekhar, M., Ghernaout, B. and Boucherit, A. (2017) Enhanced Coagulation for Algae Removal in a Typical Algeria Water Treatment Plant. Environmental Engineering and Management Journal, 16, 2303-2315. https://doi.org/10.30638/eemj.2017.238

[31] Kellali, Y. and Ghernaout, D. (2019) Physicochemical and Algal Study of Three Dams (Algeria) and Removal of Microalgae by Enhanced Coagulation. Applied Engineering, 3, 56-64.

[32] Ghernaout, D. (2019) Electrocoagulation Process for Microalgal Biotechnology-A Review. Applied Engineering, 3, 85-94.

[33] Ghernaout, D. (2014) The Hydrophilic/Hydrophobic Ratio vs. Dissolved Organics Removal by Coagulation-A Review. Journal of King Saud University-Science, 26, 169-180. https://doi.org/10.1016/j.jksus.2013.09.005 
[34] Ghernaout, D., Al-Ghonamy, A.I., Boucherit, A., Ghernaout, B., Naceur, M.W., Ait Messaoudene, N., Aichouni, M., Mahjoubi, A.A. and Elboughdiri, N.A. (2015) Brownian Motion and Coagulation Process. American Journal of Environmental Protection, 4, 1-15. https://doi.org/10.11648/j.ajeps.s.2015040501.11

[35] Kitajima, M., Ahmed, W., Bibby, K., Carducci, A., Gerba, C.P., Hamilton, K.A., Haramoto, E. and Rose, J.B. (2020) SARS-CoV-2 in Wastewater: State of the Knowledge and Research Needs. Science of the Total Environment. https://doi.org/10.1016/j.scitotenv.2020.139076

[36] Zhu, N., Zhang, D., Wang, W., Li, X., Yang, B., Song, J., Zhao, X., Huang, B., Shi, W., Lu, R., Niu, P., Zhan, F., Ma, X., Wang, D., Xu, W., Wu, G., Gao, G.F. and Tan, W. (2020) A Novel Coronavirus from Patients with Pneumonia in China, 2019. The New England Journal of Medicine, 382, 727-733. https://doi.org/10.1056/NEJMoa2001017

[37] Ghernaout, D. and Elboughdiri, N. (2019) Iron Electrocoagulation Process for Disinfecting Water-A Review. Applied Engineering, 3, 154-158.

[38] Ghernaout, D. (2019) Disinfection via Electrocoagulation Process: Implied Mechanisms and Future Tendencies. EC Microbiology, 15, 79-90.

[39] Ghernaout, D. and Elboughdiri, N. (2019) Mechanistic Insight into Disinfection Using Ferrate(VI). Open Access Library Journal, 6, e5946.

[40] Ghernaout, D. and Elboughdiri, N. (2019) Water Disinfection: Ferrate(VI) as the Greenest Chemical-A Review. Applied Engineering, 3, 171-180.

[41] Ghernaout, D. and Elboughdiri, N. (2020) Strategies for Reducing Disinfection By-Products Formation during Electrocoagulation. Open Access Library Journal, 7, e6076. https://doi.org/10.4236/oalib.1106076

[42] Ghernaout, D. and Elboughdiri, N. (2020) Electrocoagulation Process in the Context of Disinfection Mechanism. Open Access Library Journal, 7, e6083.

[43] Ghernaout, D. and Elboughdiri, N. (2020) Disinfection By-Products: Presence and Elimination in Drinking Water. Open Access Library Journal, 7, e6140.

[44] Ghernaout, D. and Elboughdiri, N. (2020) Controlling Disinfection By-Products Formation in Rainwater: Technologies and Trends. Open Access Library Journal, 7, e6162. https://doi.org/10.4236/oalib.1106162

[45] Ghernaout, D., Elboughdiri, N., Ghareba, S. and Salih, A. (2020) Electrochemical Advanced Oxidation Processes (EAOPs) for Disinfecting Water-Fresh Perspectives. Open Access Library Journal, 7, e6257. https://doi.org/10.4236/oalib.1106257

[46] Lodder, W. and de Roda Husman, A. (2020) SARS-CoV-2 in Wastewater: Potential Health Risk, But Also Data Source. The Lancet Gastroenterology and Hepatology, 1253, 30087. https://doi.org/10.1016/S2468-1253(20)30087-X

[47] Haramoto, E., Kitajima, M., Katayama, H., Ito, T. and Ohgaki, S. (2009) Development of Virus Concentration Methods for Detection of Koi Herpesvirus in Water. Journal of Fish Diseases, 32, 297-300. https://doi.org/10.1111/j.1365-2761.2008.00977.x

[48] Ye, Y., Ellenberg, R.M., Graham, K.E. and Wigginton, K.R. (2016) Survivability, Partitioning, and Recovery of Enveloped Viruses in Untreated Municipal Wastewater. Environmental Science \& Technology, 50, 5077-5085. https://doi.org/10.1021/acs.est.6b00876

[49] Wong, M.V.M., Hashsham, S.A., Gulari, E., Rouillard, J.M., Aw, T.G. and Rose, J.B. (2013) Detection and Characterization of Human Pathogenic Viruses Circulating in Community Wastewater Using Multi Target Microarrays and Polymerase Chain 
Reaction. Journal of Water and Health, 11, 659-670. https://doi.org/10.2166/wh.2013.322

[50] Bibby, K. and Peccia, J. (2013) Identification of Viral Pathogen Diversity in Sewage Sludge by Metagenome Analysis. Environmental Science \& Technology, 47, 1945-1951. https://doi.org/10.1021/es305181x

[51] Blanco, A., Abid, I., Al-Otaibi, N., Pérez-Rodríguez, F.J., Fuentes, C., Guix, S., Pintó, R.M. and Bosch, A. (2019) Glass Wool Concentration Optimization for the Detection of Enveloped and Non-Enveloped Waterborne Viruses. Food and Environmental Virology, 11, 184-192. https://doi.org/10.1007/s12560-019-09378-0

[52] McKinney, K.R., Gong, Y.Y. and Lewis, T.G. (2006) Environmental Transmission of SARS at Amoy Gardens. Journal of Environmental Health, 68, 26-30.

[53] Sinclair, R.G., Choi, C.Y., Riley, M.R. and Gerba, C.P. (2008) Pathogen Surveillance through Monitoring of Sewer Systems. Advances in Applied Microbiology, 65, 249-269. https://doi.org/10.1016/S0065-2164(08)00609-6

[54] Ghernaout, D., Elboughdiri, N., Ghareba, S. and Salih, A. (2020) Disinfecting Water with the Carbon Fiber-Based Flow-Through Electrode System (FES): Towards Axial Dispersion and Velocity Profile. Open Access Library Journal, 7, e6238. https://doi.org/10.4236/oalib.1106238

[55] Ghernaout, D., Elboughdiri, N., Alghamdi, A. and Ghernaout, B. (2020) Trends in Decreasing Disinfection By-Products Formation during Electrochemical Technologies. Open Access Library Journal, 7, e6337. https://doi.org/10.4236/oalib.1106337

[56] Johansson, M.A., Vasconcelos, P.F.C. and Staples, J.E. (2014) The Whole Iceberg: Estimating the Incidence of Yellow Fever Virus Infection from the Number of Severe Cases. Transactions of the Royal Society of Tropical Medicine and Hygiene, 108, 482-487. https://doi.org/10.1093/trstmh/tru092

[57] Ghernaout, D., Ghernaout, B. and Naceur, M.W. (2011) Embodying the Chemical Water Treatment in the Green Chemistry-A Review. Desalination, 271, 1-10. https://doi.org/10.1016/j.desal.2011.01.032

[58] Ghernaout, D. (2018) Electrocoagulation Process: Achievements and Green Perspectives. Colloid and Surface Science, 3, 1-5. https://doi.org/10.11648/j.css.20180301.11

[59] Okabayashi, T., Yokota, S.I., Ohkoshi, Y., Ohuchi, H., Yoshida, Y., Kikuchi, M., Yano, K. and Fujii, N. (2008) Occurrence of Norovirus Infections Unrelated to Norovirus Outbreaks in an Asymptomatic Food Handler Population. Journal of Clinical Microbiology, 46, 1985-1988. https://doi.org/10.1128/JCM.00305-08

[60] Bonanno Ferraro, G., Mancini, P., Veneri, C., Iaconelli, M., Suffredini, E., Brandtner, D. and La Rosa, G. (2020) Evidence of Saffold Virus Circulation in Italy Provided through Environmental Surveillance. Letters in Applied Microbiology, 70, 102-108. https://doi.org/10.1111/lam.13249

[61] Mizumoto, K., Kagaya, K., Zarebski, A. and Chowell, G. (2020) Estimating the Asymptomatic Proportion of Coronavirus Disease 2019 (COVID-19) Cases on Board the Diamond Princess Cruise Ship, Yokohama, Japan, 2020. Eurosurveillance, 25, 1-5. https://doi.org/10.2807/1560-7917.ES.2020.25.10.2000180

[62] Wang, X.W., Li, J., Guo, T., Zhen, B., Kong, Q., Yi, B., Li, Z., Song, N., Jin, M., Xiao, W., Zhu, X., Gu, C., Yin, J., Wei, W., Yao, W., Liu, C., Li, J., Ou, G., Wang, M., Fang, T., Wang, G., Qiu, Y., Wu, H., Chao, F. and Li, J. (2005) Concentration and Detection of SARS Coronavirus in Sewage from Xiao Tang Shan Hospital and the 309th Hospital of the Chinese People's Liberation Army. Water Science \& Technology, 52, 213-221. https://doi.org/10.2166/wst.2005.0266 
[63] Ghernaout, D., Naceur, M.W. and Aouabed, A. (2011) On the Dependence of Chlorine By-Products Generated Species Formation of the Electrode Material and Applied Charge during Electrochemical Water Treatment. Desalination, 270, 9-22. https://doi.org/10.1016/j.desal.2011.01.010

[64] Ghernaout, D. and Elboughdiri, N. (2020) Is Not It Time to Stop Using Chlorine for Treating Water? Open Access Library Journal, 7, e6007.

[65] Ghernaout, D., Moulay, S., Ait Messaoudene, N., Aichouni, M., Naceur, M.W. and Boucherit, A. (2014) Coagulation and Chlorination of NOM and Algae in Water Treatment: A Review. International Journal of Environmental Monitoring and Analysis, 2, 23-34. https://doi.org/10.11648/j.ijema.s.2014020601.14

[66] Ghernaout, D. (2017) Water Treatment Chlorination: An Updated Mechanistic Insight Review. Chemistry Research Journal, 2, 125-138.

[67] Ghernaout, D., Alghamdi, A., Aichouni, M. and Touahmia, M. (2018) The Lethal Water Tri-Therapy: Chlorine, Alum, and Polyelectrolyte. World Journal of Applied Chemistry, 3, 65-71. https://doi.org/10.11648/j.wjac.20180302.14

[68] Ghernaout, D. and Elboughdiri, N. (2020) Foresight Look on the Disinfection By-Products Formation. Open Access Library Journal, 7, e6349.

[69] Gundy, P.M., Gerba, C.P. and Pepper, I.L. (2009) Survival of Coronaviruses in Water and Wastewater. Food and Environmental Virology, 1, 10-14. https://doi.org/10.1007/s12560-008-9001-6

[70] Casanova, L., Rutala, W.A., Weber, D.J. and Sobsey, M.D. (2009) Survival of Surrogate Coronaviruses in Water. Water Research, 43, 1893-1898. https://doi.org/10.1016/j.watres.2009.02.002

[71] Ghernaout, D. and Elboughdiri, N. (2020) Solar Treatment in the Core of the New Disinfection Technologies. Chemical Science \& Engineering Research, 2, 6-11.

[72] Ghernaout, D., Alghamdi, A., Touahmia, M., Aichouni, M. and Ait Messaoudene, N. (2018) Nanotechnology Phenomena in the Light of the Solar Energy. Journal of Energy, Environmental \& Chemical Engineering, 3, 1-8. https://doi.org/10.11648/j.jeece.20180301.11

[73] Al Arni, S., Amous, J. and Ghernaout, D. (2019) On the Perspective of Applying of a New Method for Wastewater Treatment Technology: Modification of the Third Traditional Stage with Two Units, One by Cultivating Microalgae and Another by Solar Vaporization. International Journal of Environmental Sciences \& Natural Resources, 16, Article ID: 555934. https://doi.org/10.19080/IJESNR.2019.16.555934

[74] Ghernaout, D., Aichouni, M. and Touahmia, M. (2019) Mechanistic Insight into Disinfection by Electrocoagulation-A Review. Desalination and Water Treatment, 141, 68-81. https://doi.org/10.5004/dwt.2019.23457

[75] Ghernaout, D. (2019) Greening Electrocoagulation Process for Disinfecting Water. Applied Engineering, 3, 27-31.

[76] Ghernaout, D. (2019) Electrocoagulation and Electrooxidation for Disinfecting Water: New Breakthroughs and Implied Mechanisms. Applied Engineering, 3, 125-133.

[77] Ghernaout, D. and Naceur, M.W. (2011) Ferrate(VI): In Situ Generation and Water Treatment-A Review. Desalination and Water Treatment, 30, 319-332. https://doi.org/10.5004/dwt.2011.2217

[78] Ghernaout, D. (2018) Magnetic Field Generation in the Water Treatment Perspectives: An Overview. International Journal of Advances in Applied Sciences, 5, 193-203. https://doi.org/10.21833/ijaas.2018.01.025 
[79] Ghernaout, D., Aichouni, M. and Alghamdi, A. (2018) Applying Big Data (BD) in Water Treatment Industry: A New Era of Advance. International Journal of Advances in Applied Sciences, 5, 89-97. https://doi.org/10.21833/ijaas.2018.03.013

[80] Ghernaout, D. and El-Wakil, A. (2017) Requiring Reverse Osmosis Membranes Modifications-An Overview. American Journal of Chemical Engineering, 5, 81-88. https://doi.org/10.11648/j.ajche.20170504.15

[81] Ghernaout, D. (2017) Reverse Osmosis Process Membranes Modeling-A Historical Overview. Journal of Civil, Construction and Environmental Engineering, 2, 112-122.

[82] Ghernaout, D., El-Wakil, A., Alghamdi, A., Elboughdiri, N. and Mahjoubi, A. (2018) Membrane Post-Synthesis Modifications and How It Came about. International Journal of Advances in Applied Sciences, 5, 60-64. https://doi.org/10.21833/ijaas.2018.02.010

[83] Ghernaout, D., Simoussa, A., Alghamdi, A., Ghernaout, B., Elboughdiri, N., Mahjoubi, A., Aichouni, M. and El-Wakil, A.E.A. (2018) Combining Lime Softening with Alum Coagulation for Hard Ghrib Dam Water Conventional Treatment. International Journal of Advances in Applied Sciences, 5, 61-70. https://doi.org/10.21833/ijaas.2018.05.008

[84] Djezzar, S., Ghernaout, D., Cherifi, H., Alghamdi, A., Ghernaout, B. and Aichouni, M. (2018) Conventional, Enhanced, and Alkaline Coagulation for Hard Ghrib Dam (Algeria) Water. World Journal of Applied Chemistry, 3, 41-55. https://doi.org/10.11648/j.wjac.20180302.12

[85] Ghernaout, D., Ghernaout, B. and Kellil, A. (2009) Natural Organic Matter Removal and Enhanced Coagulation as a Link between Coagulation and Electrocoagulation. Desalination and Water Treatment, 2, 203-222. https://doi.org/10.5004/dwt.2009.116

[86] Boucherit, A., Moulay, S., Ghernaout, D., Al-Ghonamy, A.I., Ghernaout, B., Naceur, M.W., Ait Messaoudene, N., Aichouni, M., Mahjoubi, A.A. and Elboughdiri, N.A. (2015) New Trends in Disinfection By-Products Formation upon Water Treatment. Journal of Research \& Developments in Chemistry, 2015, Article ID: 628833. https://doi.org/10.5171/2015.628833

[87] Ghernaout, D. (2018) Disinfection and DBPs Removal in Drinking Water Treatment: A Perspective for a Green Technology. International Journal of Advances in Applied Sciences, 5, 108-117. https://doi.org/10.21833/ijaas.2018.02.018

[88] Ghernaout, D., Touahmia, M. and Aichouni, M. (2019) Disinfecting Water: Electrocoagulation as an Efficient Process. Applied Engineering, 3, 1-12.

[89] Ghernaout, D. and Elboughdiri, N. (2020) Vacuum-UV Radiation at $185 \mathrm{~nm}$ for Disinfecting Water. Chemical Science \& Engineering Research, 2, 12-17.

[90] Ghernaout, D. and Elboughdiri, N. (2020) UV-C/ $/ \mathrm{H}_{2} \mathrm{O}_{2}$ and Sunlight $/ \mathrm{H}_{2} \mathrm{O}_{2}$ in the Core of the Best Available Technologies for Dealing with Present Dares in Domestic Wastewater Reuse. Open Access Library Journal, 7, e6161. https://doi.org/10.4236/oalib.1106161

[91] Ghernaout, D. and Elboughdiri, N. (2020) Towards Enhancing Ozone Diffusion for Water Disinfection-Short Notes. Open Access Library Journal, 7, e6253. 